\title{
Knowledge Sharing in Schools:
}

\section{A Key to Developing Professional Learning Communities}

\author{
Marit Rismark (Corresponding author) \\ Department of Adult learning ad Counselling \\ Norwegian University of Science and Technology \\ N-7491 Trondheim, Norway
}

Tel: 47-735-928-001 E-mail: marit.rismark@svt.ntnu.no

Astrid M. Sølvberg

Department of Adult learning ad Counselling

Norwegian University of Science and Technology

N-7491 Trondheim, Norway

Tel: 47-735-928-001 E-mail: astrid.solvberg@svt.ntnu.no

Received: May 31, 2011

doi:10.5430/wje.v1n2p150
Accepted: June 15, 2011 Published: October 1, 2011

URL: http://dx.doi.org/10.5430/wje.v1n2p150

The research is financed by The Research Council of Norway.

\begin{abstract}
The purpose of this text is to explore how schools can become professional learning communities, involving teachers who continuously engage in building and sharing knowledge. We use theory and a model of knowledge conversion from the field of organizational learning to explore knowledge sharing within schools. The presented findings are based on a research project in a Norwegian secondary school. The data analysis discusses two circumstances of knowledge sharing, captured in the categories creation moments and bumpy moments. While knowledge sharing activities at team levels led to knowledge creation moments, whole staff assemblies proved to be challenging meeting places and bumpy moments occurred. We suggest that knowledge sharing as a key to developing professional learning communities needs to be organizationally supported.
\end{abstract}

Keywords: Knowledge sharing, Professional learning communities, Knowledge creation, Workplace learning, Teacher learning

\section{Introduction}

In Norway the national overriding school reform entitled Knowledge Promotion was launched in 2006. This reform challenges schools to develop into professional learning communities (White paper no. 30, 2003-2004). Being professional learning communities means that schools and teachers focus on workplace learning to the benefit of student learning. According to Evans, Hodkinson, Rainbird \& Unvin (2006), workplace learning means practices of learning, in, for, and through the workplace. In light of this, the term 'learning' exceeds the traditional notion of individuals 'acquiring knowledge', and learning is socio-culturally perceived as rooted in action in the organization and workplace culture. Bearing in mind that workplaces shape and are shaped by individual actions and interactions at work, with learning occurring through these processes (Ellström, 2010), a key point here is how schools can become workplaces that create opportunities for teachers to learn.

The Norwegian school reform clearly emphasizes that the lack of a tradition in sharing individual and collective knowledge may impede schools in their attempts to develop into professional learning communities. Thus, teachers are encouraged to build and share knowledge with colleagues. Research literature indicates that schools may not yet have tapped the potential for dissemination of knowledge among teachers (e.g. Little, Gearhart, Curry \& Kafka, 2003; Houseman \& Martinez, 2000). Although teachers in fact find the dissemination of other teachers' knowledge to be a 
useful source of learning (Collinson \& Cook, 2003; Mawhinney, 2010), studies show that knowledge sharing among teachers is scarce (Collinson \& Cook, 2000). While the Norwegian school reform is clear about the importance of knowledge sharing, it is not as clear when it comes to how schools should organize their daily work to develop practices for knowledge sharing among teachers to the benefit of student learning. Bearing all this in mind, a highly relevant issue is how schools can promote professional learning communities, involving teachers who continuously engage in building and sharing knowledge. The purpose of this article is to shed light on this issue by exploring knowledge-sharing processes among teachers.

Along with the Norwegian school reform, the Norwegian Ministry of Education and Research initiated a program in practice-oriented research and development (R\&D) in 2005. The program funded projects that encouraged close cooperation between researchers and teachers to develop school practices. With this guiding framework, a group of researchers invited a school to participate in a joint project where the partners collaborated on writing a funding application. When this application was consequently granted, a three-year R\&D project was launched in the autumn of 2006. The overriding aim of the project was to develop the school as a learning organization to the benefit of student learning. During the project period seven researchers collaborated with the school on development in accordance with this aim. Two of the researchers, the authors of this article, conducted an overall study of the knowledge-sharing processes among the teachers in the school. Data material from this sub-study is presented in this article. The conceptual framework for exploring knowledge sharing among the teachers draws upon Nonaka and Takeuchi's work on organizational knowledge creation (Nonaka, 2007; Nonaka \& Takeuchi, 1995). This theoretical approach implies that the school is perceived as an organization in line with any other workplace. In the sections that follow we present the conceptual framework and outline the research methods and the field arrangements. Then we present in-field illustrations of knowledge sharing which are analyzed according to the conceptual framework on knowledge creation. From this foundation we argue that knowledge sharing may be put into practice in a step-by-step approach to develop schools as professional learning communities.

\section{Conceptual Framework}

Contemporary research literature on learning communities highlights the importance of collaboration and meaningful interaction among teachers (e.g. Avalos, 2010; James, \& Cormick, 2009; Krečič \& Grmek, 2008). The idea of knowledge-of-practice, a main element in research on learning communities (Wood, 2007), refers to the deliberate construction of knowledge by communities of teachers drawing on outside experts and also inquiring into their daily practice (Cochran-Smith \& Lytle, 1999). This involves a vision of teachers that exceeds the function of technicians implementing other's ideas. Teachers must be reflective practitioners and need to be thinkers, inquirers and conceptualizers (Schon, 1987) when they engage in building and sharing knowledge to develop schools as professional learning communities. When they do this, teachers are not only users of pedagogic knowledge but also creators and disseminators of it. Lack of collaboration and meaningful interaction between teachers may leave us with schools where effective teaching practices are seldom shared and shoddy teaching is rarely identified or confronted (Little, et al., 2003). For example, Dewey (1970) maintains that the "successes of excellent teachers tend to be born and die with them" if schools do not become workplaces encouraging deliberate construction and dissemination of knowledge.

Nonaka and Takeuchi (1995) have developed a model for knowledge creation. They propose a spiral model in which the relationship between the epistemological and the ontological dimension of knowledge creation is essential. The epistemological dimension builds on Michael Polanyi's (1967) distinction between tacit knowledge and explicit knowledge. Tacit knowledge is personal, context specific, rooted in action and hence hard to communicate. Explicit knowledge, on the other hand, refers to knowledge that is transmittable in formal, systematic language. The epistemological dimension embraces a continual dialogue between tacit and explicit knowledge which fosters the creation of new ideas and concepts. Although ideas are formed this way in the minds of individuals, interaction between individuals typically plays a critical role in developing them. Such "communities of interaction" contribute to the amplification and development of new knowledge. This ontological dimension of knowledge creation refers to the extent to which there is social interaction between individuals who share and develop knowledge (Nonaka, 2007).

Figure 1 is based on Nonaka and Takeuchi's (1995) model of knowledge conversion and Lin et al.'s (2008) adaptations of this model. The model has four modes of "knowledge conversion", referring to the assumption that human knowledge is created and expanded through conversion between tacit knowledge and explicit knowledge (ibid). They are as follows: (1) From tacit knowledge to tacit knowledge, referred to as socialization; (2) from tacit knowledge to explicit knowledge, referred to as externalization, (3) from explicit knowledge to explicit knowledge, referred to as combination; and (4) from explicit knowledge to tacit knowledge, referred to as internalization.

$<$ Figure 1 about here $>$ 
The first mode, "socialization", enables the conversion of tacit knowledge through interaction between individuals. One assumption is that individuals can acquire tacit knowledge through experience, without language. The classical example is apprenticeship (Lave \& Wenger, 2008), where apprentices work with mentors and learn through observation, imitation, and practice. The second mode, "externalization", relates to the conversion of tacit knowledge into explicit knowledge, a process whereby individual tacit knowledge is articulated into explicit concepts through dialogue or collective reflection within a group. The third mode, "combination", involves the use of social processes to combine different bodies of explicit knowledge held by groups of individuals. This involves reconfiguring existing information through sorting, adding, recategorizing, and recontextualizing explicit knowledge into possible new knowledge at the organizational level. The fourth mode, "internalization", relates to the conversion of explicit knowledge into tacit knowledge, and is closely related to Dewey's (1970) notion of "learning by doing", which in this model involves the internalization of experiences through socialization, externalization, and combination into valuable assets of tacit knowledge bases in the form of shared mental models or technical know-how.

According to Nonaka (2007) the four patterns of interaction between tacit and explicit knowledge represent ways in which existing knowledge can be "converted" into new knowledge through a dynamic interaction between the different modes of knowledge conversion. Knowledge creation centers on the building of both tacit and explicit knowledge, and on the interchange between these two aspects of knowledge through "internalization" and "externalization". Failure to build a dialogue between tacit and explicit knowledge may cause problems in that both pure "combination" and "socialization" have shortcomings. For example, the "sharability" of knowledge created by pure socialization may be limited. This knowledge may therefore be difficult to apply in fields beyond the specific context in which it was created. All four modes need to be organizationally managed to form a continual cycle if organizational knowledge creation is to take place. These cycles may pave the way to professional learning communities. Such ambitions are certainly not only individual acts. Schools that focus on learning and development aspire towards involving everyone in the system in expressing their aspirations, building their awareness, and developing their capabilities together (Senge, 2007). In discussions on learning environments and work situations, such factors as participation, reflection, recognition, and team work are promoted as learning conditions, embedded in the organization and the learning process (Evans et al., 2006). In this way, learning processes emerge from the social context, and in more concrete forms workplace learning can be learning by observing others, learning through the sharing of experience and knowledge, learning through mentoring situations, learning from mistakes, and learning through individual or collective reflection (Høyrup, 2010).

\section{Methodology}

This article reports findings from a larger project with the overriding aim of developing a school as a learning organization to the benefit of student learning. Our sub-study of knowledge sharing among teachers draws on a case study approach (Creswell, 1998; Stake, 1995). In the empirical study we used multiple sources of information to explore knowledge-sharing activities within the bounded system of a school over a two-year period.

\subsection{Field arrangements}

The school involved in the R\&D project has students from first grade through to 10th grade, and is situated in a suburban area outside Trondheim, the third largest city in Norway. During the project period 40 teachers were employed at the school. The 480 students mainly come from middle-class families, and there were few immigrants in the school community. The teachers in the school were already organized into three working teams; team 1 (grades one through four), team 2 (grades five through seven), and team 3 (eighth, ninth, and tenth grades). One teacher in each team functioned as the team leader. In the R\&D project teachers in all teams engaged in mutual efforts to develop the school as a learning organization to the benefit of student learning.

According to Dewey's ideas on the professional development of teachers (1970), engagement in collective inquiry is essential for the construction of knowledge from practice. He suggested a laboratory model for schools where teachers engage in collective inquiry in order to weigh their practices and innovations against empirical evidence and critical dialogue. His approach included systematic observations and analyses, conducted by teachers, of learning and teaching in classrooms. The process, he argued, ought to include focused professional conversations among colleagues, which in turn stimulate innovation and further inquiry. This process would culminate in ongoing building and sharing knowledge from practice. An assumption that is built into Nonaka and Takeuchi's (1995) knowledge creation model is that organizations continuously create new knowledge by reconstructing existing perspectives, frameworks, or premises on a day-to-day basis. Argyris \& Schön (1978) argue that the questioning and reconstruction of existing perspectives, interpretation frameworks, or decision premises, can be very difficult for organizations to implement by themselves. Therefore, they suggest that some kind of artificial intervention such as the use of organizational development programs is required. Nonaka (2007) points out a limitation in this argument in that it assumes implicitly that someone inside or 
outside an organization knows objectively the right time and method for intervention. In accordance with these arguments, a basic assumption in our R\&D project was that developments should start from within and from the bottom, from the teachers themselves. It was the insiders, the teachers, who were "the knowers" of areas of improvement. The teachers were the prime movers for the areas of development throughout the project period. A necessary precondition when teachers work on improving their teaching practices is an experienced need on the part of the practitioners to initiate change and make innovations (Elliot, 1991).

During the project period seven researchers collaborated with the school staff to develop the school as a learning organization according to the overall project aim. Five of the researchers worked together with the teachers in the three teams. The researchers functioned as coaches who supported the teachers in their efforts to develop the school as a learning organization to the benefit of student learning. During the project period, the development of classroom practices within each team centered on these target areas: Team 1; portfolio assessment (Eikseth \& Steen-Olsen, 2008), Team 2; adapted teaching (Moen, 2005 \& 2009; Lyngsnes, 2009) and Team 3; students' learning strategies (Postholm, 2008). Teachers were encouraged to share knowledge about these target areas, both within and between teams. Two of the researchers, the authors of this article, studied these collective knowledge-sharing endeavors.

According to Senge (2007, p. 327) a strong professional community encourages collective endeavor, rather than isolated, individual efforts. At the basic level, the fundamental learning units in an organization are working teams, people who need one another to produce an outcome (Senge, 2006, p.xi). In the R\&D project the established teacher teams were developed further and meeting places were set up to encourage collective endeavors and sharing of knowledge and experience. Whole days (1) were set aside where the teachers could talk together and work on the on-going development activities. Systems were also developed (2) for observation classes where, according to a schedule, they could observe each other's teaching with subsequent reflection conversations. The purpose of the observations was not to assess the teaching, but to provide a tool that could stimulate change and development of the practice. These activities were meant to move teachers towards establishing "intersubjectivity". As understood here, intersubjectivity means the degree to which interlocutors in a communicative situation share a perspective and know that they share it (Rommetveit, 1974; Wertsch, 1984). Intersubjectivity appears to be a constructive force of the inter-related dynamic dialogical process, and it may thus be an asset to learning (Author \& Author, 2007; Author, author, Strømme \& Hokstad, 2007). When interlocutors establish intersubjectivity, the exchange of ideas, comments, and questions are main features of the dialog.

\subsection{Data collection and analysis}

Over a two-year in-field period we collected data on various knowledge-sharing activities through interviews and observations. The data collection period involved observations of knowledge-sharing activities with all the teachers and school staff present. We also observed knowledge-sharing activities among the teachers in smaller groups, for example team meetings. Furthermore, we observed seminars and lectures that were arranged for the school staff based on teacher-initiated topics. During every observation we wrote extensive field notes and tape-recorded all dialogs. After observations we transcribed the dialogs word for word. We conducted recurrent interviews, covering both year 1 and year 2 of the in-field period, with the principal, the vice principal, and the current team leaders in each academic year. The team leaders were encouraged to elaborate on knowledge sharing within the development areas, within the team, and within the school as a whole. The interviews were also tape-recorded and transcribed. The data material also comprises field notes of conversations with groups of teachers, minutes from leader-team meetings (principal, vice principal, and team leaders), and teacher logs. The data material amounts to well over 300 transcribed, single-spaced pages.

According to the conceptual framework for knowledge creation, all four modes of knowledge conversion are essential for forming a continuous cycle if organizational knowledge creation is to take place. Using this framework we collected data during knowledge-sharing activities to shed light on how schools can develop into professional learning communities. One of these activities involved the teachers in the teams observing each other's teaching. The researchers who worked together with the teachers in each team also participated during the observations. Before the class observation was to take place, the teacher sent a planning document to the observing teachers and to the researcher. This document described the subject/theme and the aims of the lesson, and the teacher wrote questions about the plans and activities for the lesson and specifically pointed at areas for feedback. One main assumption is that teachers possess tacit knowledge (Wood, 2007) and that colleagues can acquire some insights into each other's tacit knowledge by observing each other's teaching.

The opportunity to share first-hand teaching experiences relates to the conversion mode Socialization, as the intention of the observations of colleagues was to encourage the tacit knowledge to tacit knowledge conversion between the teachers. We conducted interviews with individual teachers and had conversations with groups of teachers about knowledge 
sharing that allowed for socialization. Some extracts in the field notes and transcripts from additional knowledge-sharing activities also provide information on how the teachers view observing other teachers' teaching. Another knowledge-sharing activity in the school may be related to the conversion mode Externalization, as teachers had the opportunity to articulate tacit knowledge into explicit concepts through dialog and collective reflection. An example of such knowledge sharing was that the teachers who observed each other's classroom activities also sat down to discuss and reflect on the shared experience. Teachers also engaged in team discussions on their general classroom practices. We observed teacher teams during team meetings and had conversations with groups of teachers and also with teachers individually. We also conducted interviews with the team leaders. Teachers were also invited to share knowledge between the teams during staff assemblies. According to the model of knowledge conversion, such knowledge sharing may allow for a combination of different bodies of explicit knowledge that individuals had. During these gatherings each team was given time to share experiences within their areas of development. As with the teacher teams, we observed the assemblies and had conversations with groups of teachers and also with teachers individually. We also conducted interviews with team leaders. Some of the extracts in the field notes and transcripts from additional knowledge-sharing activities also touch upon a combination of different bodies of explicit knowledge individuals had. We also conducted interviews with the team leaders and had conversations with groups of teachers on the internalization of new knowledge, derived from knowledge-sharing experiences of their daily teaching practices.

The data analysis of the case involved the interplay between the researchers, transcribed data material, and theory, and was undertaken both in the field and after the data had been collected. The categories we developed through analysis naturally emerged from the data material. Categories about the knowledge-creation process among teachers in the school community evolved from the use of "knowledge sharing" as a unit of analysis. New meanings about knowledge sharing were reached through the use of direct interpretation (Creswell, 1998; Stake, 1995) by looking at single instances and pulling the data material apart and putting it back together in new, meaningful ways. The data analysis and interpretation also involved categorical aggregation (ibid.) in that we searched for a collection of instances from the data until issue-relevant meanings emerged. Theoretical assumptions of knowledge creation as a spiraling process of the four modes of knowledge conversion provided a point of departure for the development and exploration of categories during the data analysis. Such grounding in the literature may counteract bias by expanding the researchers' understanding of multiple ways of viewing the phenomenon (Morrow, 2005). During the analysis we moved back and forth between the transcribed texts and theoretical assumptions on knowledge creation. Shifting between theory and data allowed us to capture multiple instances of knowledge sharing taking place between the teachers. According to Strauss \& Corbin (1998), analysis is about maintaining a certain degree of rigor while at the same time the researchers are searching for appropriate categories, asking stimulating questions, and making comparisons from masses of unorganized raw data. We aspired to maintain a certain degree of rigor through the establishment of work procedures for mutual construction of meaning between co-researchers. We continuously read and coded small extracts of data individually before mutually developing preliminary categories of knowledge-sharing features. Credibility was also enhanced by consulting with knowledgeable colleagues who had read the field notes and the transcribed dialogues before they served as peer de-briefers. They engaged in "critical and sustained discussions" (Rossmann \& Rallis, 2003) and thus served as a mirror, reflecting our responses to the research process.

\section{Findings and Discussion}

During the project period the teachers took part in various knowledge-sharing activities that offered opportunities for conversion of tacit and explicit knowledge as delineated in the modes socialization, externalization, combination, and internalization. The teachers expressed an overall positive attitude towards knowledge sharing and they also valued the opportunities to share knowledge throughout the project period. The data analysis revealed two overriding features of knowledge sharing, captured in the two categories creation moments and bumpy moments. The teachers were convinced that the teaching staff was a knowledgeable group and knowledge sharing brought about new knowledge that was used to develop teaching practices. The data material provides a multitude of such examples in the category creation moments. Throughout the data material it is just as evident that knowledge sharing was found to be challenging. This is evident in the category bumpy moments. These two categories will shed light on the spiraling process of knowledge creation between teachers through data extracts that touch upon the conversion of tacit and explicit knowledge. The metaphor "moments" is used to call attention to the priority of dwelling with limited data extracts that make it possible to discuss the conversion of tacit and explicit knowledge according to the spiraling process of knowledge creation.

\subsection{Creation moments in knowledge sharing}

Knowledge sharing between the teachers evidently brought about new insights that developed their teaching practices. The data analysis revealed this knowledge creation in the category creation moments. In the discussion below, one 
knowledge creation moment is the point of departure for discussing how knowledge-sharing activities can pave the way to developing teaching practices. One main assumption is that knowledge creation moments can arise when teachers participate in knowledge-sharing activities relating to the spiraling process of knowledge creation that touches upon all four modes of knowledge conversion as outlined by Nonaka and Takeuchi (Nonaka, 2007; Nonaka and Takeuchi, 1995).

One team's development efforts in classroom practices focused on the theme "adaptive teaching". During the first semester it became evident that one of the first steps towards adaptive teaching was to make classroom management the center of attention as there were considerable behavioral problems in the classroom during lessons. The teachers stated that dealing with the commotion in the classroom was very exhausting. Towards the end of the project period one teacher in this team described a knowledge-creation moment:

"I've actually discovered that I used to stand there shushing students without really meaning that I wanted it to be quiet. Like, I would tell them to hush up here and there, without really expecting them to be quiet. And then I'm using up a signal which you should only use when you really want it, right? So I have really learned a lot. [...] so now when I ask for quiet, then I mean it, and this has been a major revelation for me. Really wonderful."

During the project period, this teacher has shared knowledge about classroom management with colleagues in various activities that opened for conversion of tacit and explicit knowledge as delineated in the modes socialization, externalization, combination, and internalization. Evidently, the teacher was not aware of her particular use of the word hush in her established teaching practice. This has changed, and she now has access to her individual tacit knowledge base about this aspect of her classroom practice. It seems that this knowledge is no longer only tacit. With this, the "hush moment" reflects that the teacher has expanded her knowledge on classroom management. Furthermore, her classroom practice has changed accordingly and thus, according to Nonaka (2007), knowledge is "internalized" as reflected in "action" - in the teacher's classroom practice.

The field arrangements that opened up for the process of "socialization" involved the teachers observing each other's teaching, where they could share specific contexts in which experiences are embedded. Prior to the "hush-moment", this teacher had observed colleagues teaching and was observed by others. These shared experiences provided opportunities for the elaboration of the teacher team's tacit knowledge base. The data material shows that when teachers observed others, this opened up for insights into their colleagues' tacit knowledge base that otherwise would have been difficult to access:

"I might believe that I know how they [colleagues] work, but then there are these kinds of invisible things they do, which make things work well or poorly ... there are these teacher's tricks that you learn over the years, about motivation, and about how to make the kids focus, all the basic things. What makes us succeed or not as teachers."

This utterance reflects awareness and acknowledgement of tacit knowledge in teaching. Moreover, it reflects a belief that core elements in successful teaching are rooted in insights into teachers' tacit knowledge base. Opportunities to share situations by observing colleagues may thus provide a basis for the conversion of other teachers' tacit knowledge of successful teaching. Bearing in mind that knowledge is situated (Lave \& Wenger, 2008) tacit knowledge created through teacher observations may be difficult to apply in other situations than the specific context in which it was created. However, our analysis showed that this mode of knowledge conversion was essential for the development of teaching practices. The shared experiences from teacher observations also proved to be useful for teachers when they participated in other knowledge-sharing activities that opened for externalization and combination.

In the knowledge-creation process, it is essential to encourage teachers to express their knowledge. The arranged knowledge-sharing activities opened up for such "externalization", which Nonaka and Takeuchi (1995) describe as the conversion of tacit knowledge into explicit knowledge. Although it may be challenging to articulate tacit knowledge into explicit concepts efficiently and effectively (ibid.), our data material provides examples of the significance of this process for the development of teaching practices. When the teacher in the "hush-example" and her teaching team came together for joint reflections on challenges around classroom management, they negotiated meaning in basic everyday terms, as well as theoretical concepts. The teachers strived to express their understandings of basic terms, such as: "What does "having peace to work" mean to you? and what do you actually mean when you say this"? The teacher team used several theoretical concepts in their efforts to express what classroom management actually meant. One theoretical concept that was used in the efforts to articulate tacit knowledge into explicit knowledge about classroom management was the concept of "activity genre". According to Moen (2005) this concept points out that situations that arise during a school day require their own particular form of behavior and typical form of utterances. Each situation has various implied typical activities. For example, work periods imply some types of activity, while breaks and lunches call for other typical activities: 
"We've worked closely together. We've formulated some concepts we use quite often now. Concepts that really help us a lot. Like there is a theory behind the concepts and we know something about it. For example "activity genre". When we say it, we know exactly what it's about (which behavior and expressions - activity genre - are connected to the activity "getting the class started"). And "proactive class management", like when John says this super difficult word, then I know what he understands, what he means. Right? Then he's thinking about what I need to have in mind before I go to class, what's the time now, I have to get into the classroom before the students, can't start before everything is in order, I must deliver clear messages, I need to establish contact. We talk about the importance of this. This facilitates your own work and your colleagues work. This also promotes reflection, it compels it, because then I can go back and ask ... What happened? Why? Then I can step back a bit and think.

The teachers used an established theoretical concept, "activity genre", when they participated in joint reflections on how to obtain proactive classroom management. Although they used a pre-defined theoretical concept, the teachers perceived this concept as developed within the group and refer to the concept as "constructed by us". At the outset of the joint reflections the teachers evidently operated within different conceptual worlds when it came to the understanding of proactive classroom management, and they engaged in joint reflections to negotiate meaning. Over time, the teachers established a shared understanding of the concepts proactive classroom management and activity genre. The two concepts came to reflect core aspects of teaching practices: what type of teacher behavior (be on time, be organized) and what kind of utterances (clear messages) were necessary. According to Engeström (2001) negotiating processes focus on how participants engage in concept formation. He shows how theoretical concepts may be transformed through a step-wise and seemingly thorough negotiation process. The theoretical concepts "activity genre" and "proactive classroom management" functioned as tools that assisted teachers at the team (group) level during joint reflections in their efforts to externalize their own perspectives about what classroom management actually meant. After she had participated in these knowledge-sharing activities over time, the teacher in the hush-moment expressed that "activity genre" also functioned as a personal (individual) tool. It brought insights that were internalized as reflected in her evolving teaching practice (awareness of clear messages and behavior according to the use of the word "hush").

The knowledge-sharing activities that the teachers were participating in allowed for creation moments to occur. Evidently, new insights contributed positively to the development of teaching practices both at individual and team levels. Creation moments may thus be seen as steps that move the school towards being a professional learning community.

\subsection{Bumpy moments in knowledge sharing}

As we move deeper into the analysis it becomes quite clear that knowledge sharing was not always streamlined. Knowledge did not always flow easily and straightforwardly between the teachers in the school. This is described by using the category "bumpy moments" in knowledge sharing. Bumpy moments were especially pronounced during activities that were meant to enhance knowledge sharing across teacher teams. The whole school community participated in such staff assemblies, which were held to allow for the combination of different bodies of explicit knowledge that the individual teachers and each teacher team had.

Our understanding of these knowledge-sharing activities draws upon Nonaka and Takeuchi's "combination" mode -the combination of explicit knowledge individuals have. For example, these knowledge-sharing activities made it possible to combine the concepts formed by one teacher team with existing opinions and views from the school community in search of more concrete and shareable teaching approaches. However, when the whole school came together to share knowledge between teams this seemed to be far more challenging than knowledge sharing within teams.

The teachers valued knowledge-sharing activities that involved all teacher teams and the whole school community. Without these opportunities, "something" would be missing:

... We're a primary and lower secondary school (years one to ten) and we should know what they are doing on the other levels and we want to learn from each other... It's interesting to hear, and useful to hear about what the others have been working on and how they have done it and how they have solved it. It's clear that something would have been missing if there had been no such sharing of experience because then it would only have been "in the air". And that's something we work on at a school, getting some collaboration from years one to ten.

This utterance points to the importance of keeping each other updated on what is going on in the school. An exchange of updates from colleagues' teaching practices is believed to contribute to a feeling of belonging and to a collaborating school, as well as being a means for learning from colleagues. Furthermore, listening to what other teachers have to say about what they do and how they go about it seems to be a key interest in this type of knowledge-sharing activity. As seen in the previous section, the teachers recognize the expertise of colleagues, and they believe that core elements in 
successful teaching are rooted in insights into their colleagues' tacit knowledge base. Thus, it should be no surprise that the teachers in the school express that they value listening to "what" their colleagues did and "how" they did it. However, the analyses reveal that knowledge did not always flow easily and straightforwardly between the teachers and bumpy moments occurred. Typically, the teachers strived to provide sufficient background so that other teachers could understand what was going on in the teaching practices. When we look into what the teachers told the others during these knowledge-sharing activities, the analysis shows that the teacher teams talked about their teaching practices in descriptive ways:

...We started here, and said: let's make a front page for the portfolio... ...We'll make a self-portrait in the portfolio .......Then the portfolio should contain three examples... ...after that comes the selection of products, and that involves... ...then comes the last part...

The descriptive way of sharing updates with colleagues caused bumpy moments in the teachers' knowledge-creation processes. The teacher teams provided rich descriptions from their practices. It seems that these descriptions that touch upon what they did, and how they did it, did not speak for themselves in ways that made them into learning assets for colleagues. After listening to descriptions like the one above, one teacher expressed:

"It's a difficult setting, because it really boils down to details. Perhaps it would have been possible to look at it from a meta-perspective and think "What did we actually do, and why was it good and what would we like to continue doing?"

This utterance reflects that the kind of knowledge being shared contributes to how the knowledge-sharing activity might be perceived. It also points to the importance of exceeding the description level of knowledge during knowledge-sharing activities that are meant to enhance the combination of explicit bodies of knowledge. Knowledge at the meta-level may be more appropriate when the aim is to understand the "whats" and "hows" of teaching practices. The detailed descriptions during the whole-school assemblies allow us to question how such knowledge-sharing activities may be organizationally managed so that the participants can exchange and combine explicit knowledge. Our findings suggest that one key that may prevent bumpy moments from occurring is that teachers engage in negotiations on what the descriptions may provide of relevant insights for colleagues.

Our findings show that the conversion of knowledge in the mode "combination" proved to be challenging for the school community. For the knowledge creation process to be realized at the organizational level, all four modes of knowledge creation need to be organizationally managed to form a continual cycle (Nonaka, 2007). Hence, schools need to pay special attention to how to organizationally manage knowledge-sharing activities meant to enhance knowledge creation within the combination mode. Bumpy moments may cause "discontinuity of knowledge flows" between the modes. This phenomenon refers to the fact that knowledge conversion within one mode should flow on to the other modes and contribute to further knowledge conversion (Lin, Lin \& Huang, 2008). The category bumpy moments captures some circumstances in knowledge sharing that may bring about discontinuity of knowledge flow. By identifying such circumstances in knowledge sharing, these insights may be seen as decisive steps towards developing schools as professional learning communities.

\section{Conclusion}

Our case study shows that by participating in knowledge-sharing activities, teachers actually shared knowledge, expanded their insights, and developed their teaching practices accordingly. The two categories creation moments and bumpy moments, derived from the analysis, conceptualize distinct features of the knowledge-creation process that teachers were engaged in to develop their teaching practices. Evidently, knowledge-sharing activities at the individual and team levels at the school allowed for creation moments to occur. However, knowledge did not always flow easily and straightforwardly during activities that were meant to enhance knowledge creation across all teaching teams. When all staff participated in joint knowledge-sharing activities, bumpy moments occurred. If we draw upon Nonaka and Takeuchi's (1995) conceptualization of knowledge creation, our study shows that while knowledge was converted within the modes socialization, externalization, and internalization, knowledge did not flow as easily within the combination mode. Nonaka and Takeuchi emphasize that while the tacit knowledge of individuals is the heart of knowledge creation, knowledge centers on its externalization and amplification through dynamic interactions between all four modes of knowledge conversion. Tacit knowledge is mobilized through a dynamic "entangling" of the various modes of knowledge conversion in a process that is referred to as a spiraling process of knowledge creation. If schools aspire to become professional learning communities, they need to strive towards an everyday practice that involves knowledge sharing that allows for knowledge conversion within and between all four modes. We suggest that such ambitions may need to be organizationally supported. Based on the field arrangements in our case study, it seems that the formalized plans for knowledge-sharing activities facilitated teachers' conversion of knowledge. For example, before teachers observed colleagues, they prepared a planning document that guided observations and supported teachers in their 
subsequent discussions.

Our study of knowledge-sharing activities identified some features of knowledge sharing among teachers. Additional studies are needed to identify other qualities of knowledge sharing. Such insights can assist schools in their efforts to tap the learning potential that lies in knowledge sharing. By making teacher knowledge public and open to critique, refinement, and preservation, schools can move towards becoming professional learning communities.

\section{References}

Argyris, C. \& Schön, D. A. (1978). Organizational Learning, Reading, MA: Addison-Wesley.

Author \& Author (2007). Effective dialogues in driver education. Accident Analysis and Prevention 39, 600-605. http://dx.doi.org/10.1016/j.aap.2006.10.008

Avalos, B. (in press). Teacher professional development in Teaching and Teacher Education over ten years. Teaching and Teacher Education (2010), http://dx.doi.org/10.1016/j.tate.2010.08.007.

Cochran-Smith, M. \& Lytle, S. (1999). Relationships of knowledge and practice: Teacher learning community. Review of Research in Education, 24, 249-305.

Collinson, V. \& Cook, T. F. (2000). I don't have enough time: Teachers' interpretations of time as a key to learning and school change. Paper presented at the annual meeting of the American Educational Research Association. New Orleans, LA, April 24-28.

Collinson, V. \& Cook, T. F. (2003). Learning to share, sharing to learn: Fostering organizational learning through teachers' dissemination of knowledge. Paper presented at the annual meeting of the American Educational Research Association. Chicago, IL, April 21-25.

Creswell, J. W. (1998). Qualitative inquiry and research design. Thousand Oaks: Sage.

Dewey, J. (1970). The sources of a science of education. New York: Liveright.

Doolittle, G., Sudeck, M. \& Rattigan, T. (2008). Creating professional learning communities: The work of professional development schools. Theory Into Practice, 47, 303-310. http://dx.doi.org/10.1080/00405840802329276

Elliot, J. (1991). Action research for educational change. Milton Keynes, Philadelphia: Open University Press.

Ellström, P.-E. (2010). Informal learning at work: Conditions, processes and logics. In M. Malloch, L. Cairns, K. Evans \& B.N. O'Connor (Eds.). The SAGE handbook of workplace learning (Chapter 8). Gbr: Sage Publications Ltd.

Engeström, Y., 2001. Expansive learning at work: Toward an activity theoretical reconceptualization. Journal of Education and Work, 14(1), pp. 133-156.

Evans, K., Hodkinson, P., Rainbird, H. and Unwin, L. (2006). Improving workplace learning. London and New York: Routledge.

Housmann, N.G.N. and Martinez, M.R. (2001). A Brief for Practitioners on Turning around Low-performing Schools: Implications at the school, district and state levels. Washington, D.C: National Clearing-house for Comprehensive Reform.

Høyrup, S. (2010). Employee-driven innovation and workplace learning: Basic concepts, approaches and themes. Transfer 16 (2), pp. 143-154.

James, M. \& Mc.Cormick (2009). Teachers learning how to learn. Teaching and teacher education, 25, 973-982. http://dx.doi.org/10.1016/j.tate.2009.02.023

Krečič, M.J. \& Grmek, M.I. (2008). Cooperative learning and team culture in schools: Conditions for teachers' professional development. Teaching and Teacher Education 24, 59-68.

Lave \& Wenger (2008). Situated learning. Legitimate peripheral participation. New York: Cambridge University Press.

Lin, F.; Lin, S. \& Huang, T. (2008). Knowledge sharing and creation in a teachers' professional virtual community. Computers \& Education, 50(3), 742-756. http://dx.doi.org/10.1016/j.compedu.2006.07.009

Little, J.W., Gearhart, M., Curry, M. and Kafka, J. (2003). Looking at student work for teacher learning, teacher community and school reform. Phi Delta Kappan, 83(5), 184-192.

Little , J.W. (1990). The persistence of privacy: Autonomy and initiative in teachers' professional relations. Teachers 
College Record, 91, 509-536.

Lyngsnes, K. (2009). Tilpasset opplæring, skriving og lærelyst på 6.trinn - elevers og læreres læring. I T.Steen-Olsen \& M.B. Postholm (Eds.). Å utvikle en lærende skole. Aksjonsforskning og aksjonslæring i praksis (pp. 59-73). Kristiansand: Høyskoleforlaget.

Mawhinney, L. (2010). Let's lunch and learn: Professional knowledge sharing in teachers' lounges and other congregational spaces. Teaching and Teacher Education 26, 972-978. http://dx.doi.org/10.1016/j.tate.2009.10.039

Moen, T. (2005). Activity genre: a new approach to successful inclusive teaching. Teachers and Teaching. Theory and Practice, 11(3), 257-272.

Moen, T. (2009). Dette har hjulpet meg veldig, altså. In T.Steen-Olsen \& M.B. Postholm (Eds.). Å utvikle en lærende skole. Aksjonsforskning og aksjonslæring i praksis (pp. 75-88) Kristiansand: Høyskoleforlaget.

Morrow, S. L. (2005). Quality and trustworthiness in qualitative research in counselling psychology. Journal of Counseling Psychology, 52(1), pp. 250-260. http://dx.doi.org/10.1037/0022-0167.52.2.250

Nonaka, I. (2007). A dynamic theory of organizational knowledge creation. In K. Starkey, S. Tempest \& A. McKinlay (Eds.). How Organizations Learn. Managing the search for knowledge (165-201). United Kingdom: Thomson.

Nonaka, I. \& Takeuchi, H. (1995). The knowledge-creating company. How Japanese companies create the dynamics of innovation. New York: Oxford University Press.

Polanyi, M. (1967). The tacit dimension. Garden City, N.Y.: Anchor Books.

Postholm , M.B. (2008). Teachers developing practice: Reflection as key activity. Teaching and teacher education, 24, 1717-1728. http://dx.doi.org/10.1016/j.tate.2008.02.024

Rommetveit, R. (1974). On message structure: A framework for the study of language and connection. N.Y: John Wiley.

Rossman, G. B. \& Rallis, S. F. (2003). Learning in the field: An introduction to qualitative research. Thousand Oaks, CA: Sage.

Schön, D. A. (1987) Educating the Reflective Practitioner. Toward a New Design for Teaching and Learning in the Professions. San Francisco: The Jossey-Bass Publishers.

Senge, P. M. (2006). The fifth discipline. The art and practice of the learning organization. London: Random House.

Senge, P. M. (2007). Schools that learn. A fifth discipline fieldbook for educators, parents, and everyone who cares about education. London: Nicholas Brealey Publishing.

Stake, R.R. (1995). The Art of Case Study Research. Thousand Oaks: Sage.

Steen-Olsen, T. \& Eikseth, A.G. (2008). Portfolio assessment - strategies and learning among the youngest children. Paper presentation at the symposium: Research and development work for knowledge construction in education. NERA (Nordic Educational Research Association). Copenhagen, 6 -8. mars, 2008.

Strauss, A. \& Corbin, J. (1998). Basics of Qualitative Research. Techniques and Procedures for Developing Grounded Theory. Thousand Oaks, California: SAGE Corporation, Inc.

Author, Author, Strømme, A. \& Hokstad, L.M. (2007). How mobile technology promotes effective learning. In V. Uskov (Ed.). Computers and advanced technology in education. Anaheim: Acta Press.

Wertsch, J.W. (1984). The zone of proximal development: Some conceptual issues. In B.Rogoff \& J. W. Wertsch (Eds.). Children's learning in the "Zone of proximal development". New directions for child development, 7-18. San Fransisco: Jossey-Bass.

White paper no. 30, (2003-2004). Kultur for læring. [Culture for learning]. The Department for Teaching and Research, UFD.

Wood, D. R. (2007). Professional learning communities: Teachers, knowledge, and knowing. Theory into Practice, 46(4), 281-290. http://dx.doi.org/10.1080/00405840701593865 


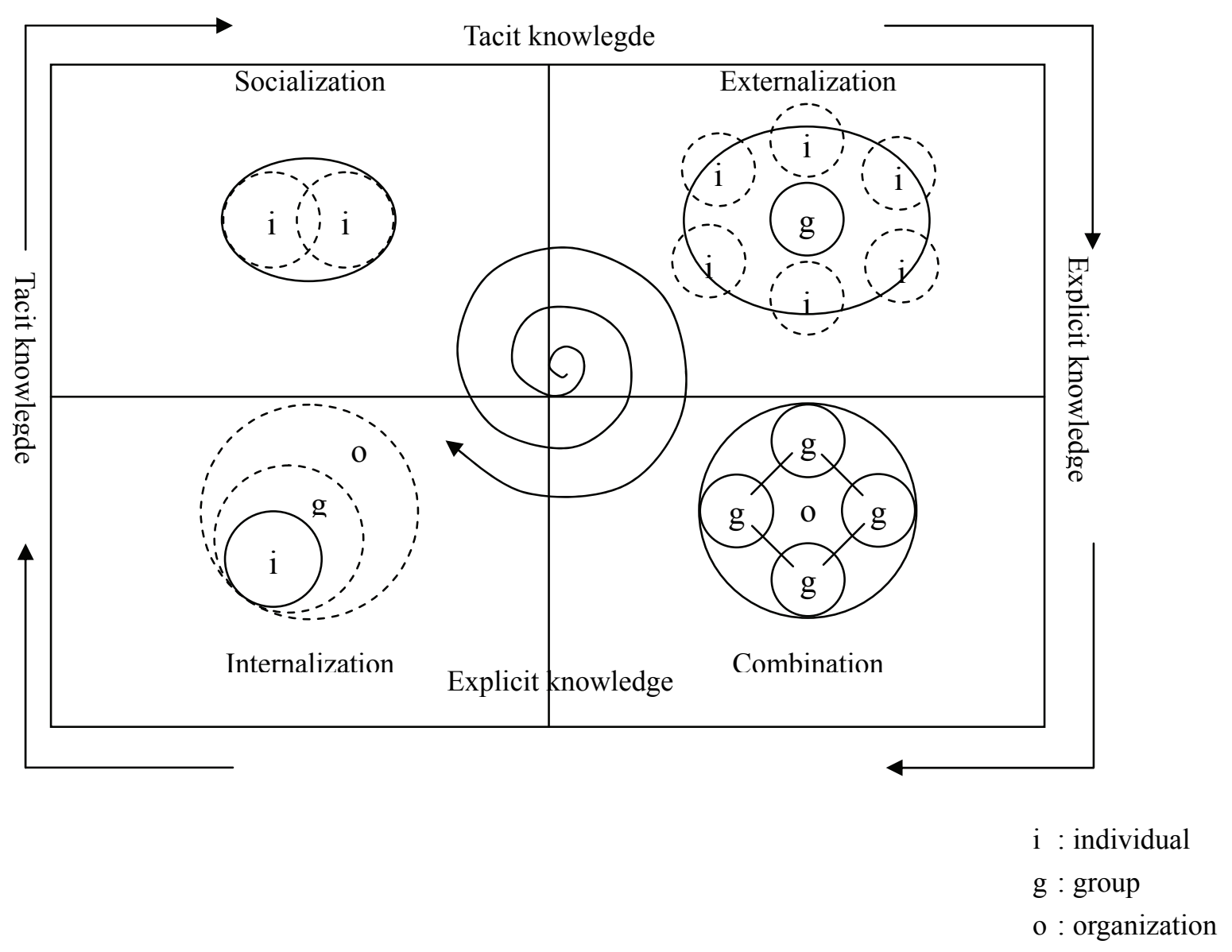

Figure 1. Four modes of knowledge conversion 